\title{
Kişisel Verilerin Korunması: Türk Bankacılık Sektörü Üzerine Kavramsal Bir Değerlendirme
}

\begin{abstract}
Mustafa Tevfik KARTAL ${ }^{1}$
ÖZ: Bu çalışma son dönemde yürürlüğe giren ve bankaların faaliyetlerini etkileyen önemli düzenlemelerden biri olan Kişisel Verilerin Korunması Kanunu'na yönelik olarak hazırlanmıştır. Söz konusu çalışma ile Türk Bankacıllı Sektöründe kişisel verilerin korunması ile ilgili çerçevenin ortaya konulması amaçlanmaktadır. Kişisel verilerin korunmasına ilișkin teorik çerçeveye ek olarak bu çalışmada bankaların kişisel verilerin korunmasında dikkat etmesi gereken kritik hususlar vurgulanmıştır. Sonuç olarak kişisel verilerin korunması bankalar ve müşterileri açısından kritik bir husus olup mevzuata uyumsuzluk halinde bundan hem bankaların hem de müşterilerinin ciddi zararlar görebileceği değerlendirilmişstir. Bu nedenle bankalarda kişisel verilerin korunması ile ilgili iç kontrol ve iç denetim mekanizmaları ihdas edilmeli, banka uygulamaları düzenli bir şekilde izlenmeli, gerektiğinde idari ve adli işlemler tesis edilmelidir. Mevzuata tam uyum sağlanmaması halinde ise bankaların ciddi yaptırımlarla karşı karşıya kalacă̆ı unutulmamalıdır.
\end{abstract}

Anahtar Kelimeler: Bankacılık, Kişisel Veri, Kişisel Verilerin Korunması, Düzenlemeler, Türkiye

Jel Kodu: G21, K23, K29

\section{Protection of Personal Data: A Conceptual Evaluation upon Turkish Banking Sector}

\begin{abstract}
This paper was prepared for Personal Data Protection Law which is one of the most important regulations that has become effective recently and has been affecting banks' activities. With this study, it is aimed at exhibiting framework regarding personal data protection levels in Turkish Banking Sector with all perspectives. In addition to personal data protection conceptual framework, some critical points that banks should take into consideration in personal data protection are addressed in this study. As a conclusion, it was evaluated that personal data protection is a critical issue in terms of banks and their customers and in case of incompliance with regulations customers and banks would get harmed seriously. For this reason, internal control and internal audit mechanism in banks should be structured with regard to personal data protection, bank's practices should be followed up, and administrative and legal actions should be taken when necessary. It should not be forgotten that banks may face serious enforcement in case of not to comply with regulations completely.
\end{abstract}

Keywords: Banking, Personal Data, Personal Data Protection, Legislations, Turkey JEL Codes: G21, K23, K29

1 Dr., Borsa İstanbul A. Ş., Stratejik Planlama ve Yatırımcı İlişkileri Direktörlüğü, mustafatevfikkartal@gmail.com, orcid.org/0000-0001-8038-8241 


\section{Giriş}

Finansal sistem içinde bulunan önemli aracılardan biri bankalardır. Türkiye'de ekonomik faaliyetlerin fonlamasının büyük bir kısmı bankalar tarafından sağlanmaktadır. Diğer bir ifadeyle, ülkedeki yatırımların sürekliliğinin sağlanabilmesi adına bankalar oldukça önemli bir yere sahiptir (Yüksel vd., 2015: 2). Bankaların bu fonksiyonu dikkate alındığında bankacılık sektörünün ülke ekonomisi için oldukça önemli bir rol oynadığı görülmektedir (Dinçer vd., 2016: 33). Bahsedilen önemi nedeniyle bankacılık faaliyetleri Bankacılık Kanunu ile (BK) düzenleme altına alınmıştır. BK, finansal piyasalarda güven ve istikrarın sağlanması, kredi sisteminin etkin bir şekilde çalışması, tasarruf sahiplerinin hak ve menfaatlerinin korunmasını amaçlamaktadır (BK, 2005: madde 1).

Türkiye gibi finansal piyasaları banka temelli olan ülkelerde bankalar sistemik öneme sahip finansal kuruluşların başında gelmektedir. Bankacılık sisteminde yaşanabilecek sorunlar Türkiye'nin ekonomisini derinden etkileme potansiyeline sahiptir. Finansal sistemdeki önemi nedeniyle sıklıkla bankacılık sektörüne yönelik yeni düzenlemeler yapılmaktadır. $\mathrm{Bu}$ düzenlemelere Türkiye Büyük Millet Meclisi'nin kanun yoluyla yaptığı düzenlemelerin yanı sıra Bankacılık Düzenleme ve Denetleme Kurumu (BDDK), Sermaye Piyasası Kurulu (SPK), Rekabet Kurumu (RK), Tasarruf Mevduatı Sigorta Fonu (TMSF), Türkiye Cumhuriyet Merkez Bankası (TCMB), Gümrük ve Ticaret Bakanlığı (GTB) tarafından görev alanlarıyla sınırlı olmak üzere yönetmelik, genelge, tebliğ yoluyla bankalar hakkında yapılan düzenlemeler örnek gösterilebilir. Diğer bir ifade ile temel olarak bankacılık sektörünün düzenlenmesine yönelik olarak 2005 yılında yürürlüğe konulan BK'nın yanı sıra düzenleyici-denetleyici kurumlar (DDK) tarafından sektörü etkileyen birçok yapılmıştır. Tüketicinin Korunması Hakkında Kanun, Banka Kartları ve Kredi Kartları Kanunu, Banka Kartları ve Kredi Kartları Hakkında Yönetmelik, Finansal Tüketicilerden Alınacak Ücretlere İlişkin Usul ve Esaslar Hakkında Yönetmelik, Bankacılık Hizmetlerinin Erişilebilirliğine Dair Yönetmelik son dönemde yapılan düzenlemelerden bazılarıdır. Bütün bu düzenlemeler bankaların müşterileri ile yaptıkları işlemlerde uyulması gereken kuralları belirlemek ve dolayısıyla hem bankaları hem de müşterileri korumak amacı ile yürürlüğe konulmuştur. Son zamanlarda bankalarla ilgili yapılan en önemli değişikliğin ise 2016 yılında yürürlüğe giren Kişisel Verilerin Korunması Kanunu (KVKK) olduğu söylenebilir.

2016 yılında yürürlüğe giren KVKK kişisel verilerin toplanması, işlenmesi, depolanması ve silinmesi ile ilgili kurallar ortaya koymaktadır. Bu kanun kuralları ihlal eden kişilere ve kurumlara ise yüklü miktarda para cezası ve hapis cezası öngörmektedir. Bu nedenle KVKK, müşteriler hakkında birçok bilgiyi bünyesinde tutan bankaları yakından ve derinden ilgilendirmektedir. Günümüzde bankacılığın kârlılık, müşteri memnuniyeti ve mevzuata uyum odaklı bir yapı üzerine kurulu hale geldiği dikkate alındığında müşteri şikâyetlerinin önlenmesi ve kârlılığın sürdürülebilmesi açısından KVKK önemli bir noktadadır. Bununla birlikte 
Uluslararası Ekonomi ve Yenilik Dergisi, 4 (1) 2018, 1-18

mevzuata uyum konusu bankalar için hiç olmadığ 1 kadar ileride bir noktaya taşınmıştır. Dolayısı ile artık bankaların kârlılıklarının önemli bir kısmının mevzuata uyumdan geleceğini söylemek mümkündür. Nitekim mevzuata uyum sağlamayan bankalara başta RK, GTB ve SPK olmak üzere DDK'lar tarafından milyar liralara yaklaşan cezaların verildiği basına yansıyan haberlerden izlenebilmektedir.

Yukarıda verilen bilgiler dikkate alındığında, bankaların müşterileri ile ilgili yoğun ve kapsamlı bilgi toplaması ve KVKK'nın çeşitli yaptırımlar içermesi nedeniyle KVKK'ya uyum konusu önem taşımaktadır. Türkiye'de literatürde KVKK ile ilgili bazı çalışmalar yer almakta olup KVKK'yı bankalara yönelik olarak ele alan bir çalışmaya rastlanmamıştır. Bu çalışmada Türk Bankacılık Sektörü (TBS) açısından KVKK'nın detaylı bir şekilde ele alınması ve Türk bankalarına olası etkilerinin değerlendirilmesi amaçlanmıştır. Böylece literatüre katkı yapılması hedeflenmiştir. Ayrıca bu çalışmada bankaların KVKK'ya uyum konusunda yerine getirmesi gereken faaliyetlere ve göz önünde bulundurması gereken hususlara yer verilmiştir.

$\mathrm{Bu}$ çalışma altı bölümden oluşmaktadır. Giriş bölümünün ardından, ikinci bölümde kişisel veri kavramı ve kişisel verileri korumanın tarihçesi ele alınmıştır. Üçüncü bölümde kişisel veriler ile ilgili literatürde yer alan bazı çalışmalar incelenmiştir. Dördüncü bölümde kişisel verilerin işlenmesine, Türkiye ve Avrupa Birliği'nde (AB) kişisel veri mevzuatına yer verilmiştir. Beşinci bölümde TBS'de kişisel verilerin korunması ve bankaların mevzuata uyum için gerçekleştirmesi gereken faaliyetler incelenmiştir. Son bölümde ise değerlendirme yapılmıştır.

\section{Kişisel Veri Kavramı ve Veri Korumanın Tarihçesi}

Kişiler ile ilişkilendirilebilen kişinin vergi numarası, yaşı, mesleği, adresi, kredi kartı bilgileri, genetik vb. bilgileri kişisel veri olarak kabul edilmektedir (Turan, 2015: 3). Ayrıca kişisel veri birey ile ilişkilendirilebilen hemen hemen her şey olarak kabul görmektedir. Bu açıdan kişinin sosyal güvenlik numarası, banka ve kredi kartı numarası, vergi numarası, sağlık verileri gibi bilgiler kişisel veri olarak değerlendirilmektedir (Turan, 2016: 2-3). Ayrıca kişisel veri kimliği belirli veya belirlenebilir gerçek kişiye ilişkin her türlü bilgi olarak da tanımlanabilmektedir (KVKK, 2016: madde 3). Diğer taraftan kişisel veri belirli ya da belirlenebilir nitelikteki kişiye ilişkin her türlü bilgi olarak da tanımlanmaktadır (Küzeci, 2010: 9; Aksoy, 2010: 11; Sevimli, 2011: 123; Kılınç, 2012: 1093).

Kişisel verilerin bir nokta ötesini hassas veriler oluşturmaktadır. Kişisel verilerin daha fazla koruma uygulanan küçük bir grubu hassas veri olarak tanımlanmaktadır (Carey, 2009: 81). AB Veri Koruma Direktifi'ne göre temel haklar ve özel yaşamın gizliliğini ihlal edici yapıda bulunan veriler hassas veri olarak tanımlanmaktadır (AB, 1995: 33).

Hassas veriler kapsamına giren türler yoluyla da tanımlanabilmektedir. Buna göre doğrudan veya dolaylı olarak kişilerin 1rk1, etnik kökeni, ten rengi, siyasi 
görüşleri, dini, sendika üyeliği, sağlık bilgileri, cinsel tercihleri, mahkûmiyet vb. gibi durumlarını ortaya çıkaran bilgiler hassas veri şeklinde tanımlanabilir. Bununla birlikte ülkeler arasında veri tanımlarında yeknesaklık bulunmamaktadır. Hassas veri kavramının yanı sıra Alman Federal Veri Koruma Kanunu'nda özel kategorili kişisel veri (special categories of personal data), Hollanda Veri Koruma Kanunu'nda özel kişisel veriler (special personal data), Avusturya Federal Kişisel Verilerin Korunması Kanunu'nda özel korumaya layı olan veriler (data deserving special protection) kavramları kullanılmaktadır (Kaya, 2011: 318).

Diğer taraftan düzenleyici otoriteler ve bireyler kişisel bilgi kavramını farklı şekilde algılamaktadırlar. İngiltere'de 2006 yılında yapılan araştırma sonuçlarına Tablo 1'de yer verilmiştir.

Tablo 1: İngiltere Kişisel Verileri Araştırma Sonuçları

\begin{tabular}{lc}
\multicolumn{1}{c}{ Veri Türü } & \% Oran \\
Finansal veriler & 88,0 \\
Sağlik bilgileri & 72,0 \\
Kişisel iletişim bilgileri & 68,0 \\
Cinsel yaşam bilgileri & 67,0 \\
Biometrik bilgiler & 63,0 \\
Genetik bilgiler & 63,0 \\
Suç kayitları & 58,0 \\
Ziyaret edilen internet sitelerine ilişkin bilgiler & 43,0 \\
Siyasi düşünceler & 42,0 \\
Eğitim bilgileri & 42,0 \\
Irk ve etnik köken bilgileri & 41,0 \\
Çalışma geçmişi bilgileri & 41,0 \\
Siyasi parti üyeliği bilgisi & 38,0 \\
Dini ve felsefi inanç bilgisi & 37,0 \\
Sendika üyeliği bilgisi & 33,0
\end{tabular}

Kaynak: Lloyd, 2008: 42-43

Tablo 1'den görüleceği üzere, normalde kişisel veriler arasında yer almayan finansal veriler araştırmada en üst sırada çıkmıştır.

Yukarıda verilen bilgiler dikkate alındığında, ülkeler arasında kişisel veri tanımının, kişisel verilere yönelik düzenleyicilerin ve bireylerin algılarının farklılık gösterdiği ortaya çıkmaktadır. Bahsedilen farklılıklar özellikle uluslararası olaylarda kişisel verilerin korunması zorlaşmaktadır.

Kişisel verilerin korunması konusu çeşitli evrelerden geçerek günümüzdeki şeklini almıştır. Söz konusu tarihsel gelişim Tablo 2'de özetlenmiştir (TikkinenPiri vd., 2017: 3-4): 
Uluslararası Ekonomi ve Yenilik Dergisi, 4 (1) 2018, 1-18

Tablo 2: Kişisel Verilerin Korunmasının Tarihsel Gelişimi

Yıl İlgili

Faaliyet/Gelişim

1948 Birleşmiş Miletler İnsan Hakları Evrensel Bildirgesi

1953 AB Konseyi İnsan Haklarının Korunmasına ve Temel Özgürlüklere İlişkin Avrupa Konvansiyonu

1973 ABD Sağlık, Eğitim ve Refah Bakanlığ

Adil Bilgilendirme Uygulamaları

(Fair Information Practices)

1974 ABD Senatosu

Gizlilik Kanunu (US Privacy Act)

1981 AB Konseyi Bireylerin Korunması Konvansiyonu

(Convention for the Protection of Individuals)

1995 AB Komisyonu Verilerin Korunması Direktifi

(Data Protection Directive 95/46 EC)

2002 AB Komisyonu

Gizlilik ve Elektronik İletişime İlişkin Direktif

(Directive on Privacy and Electronic

Communications, 2002/58/EC)

Ekonomik İşbirliği ve Gizliliğin Korunması ve Sınır Ötesi Kişisel Veri

2011 Kalkınma Örgütü Akışına İlişkin Rehber (Guidelines on the

(OECD) Protection of Privacy and Transborder Flows of

Personal Data)

Tablo 2'de yer verilen düzenlemeler, kişisel verilere ilişkin düzenlemelerin günümüze kadar şekillenmesinde rol oynayan temel gelişmelerdir. Diğer taraftan ABD'de eyalet ve sektör temelli düzenlemeler de kişisel verilerin şekillenerek günümüzdeki noktaya gelinmesinde rol oynamıştır. Ayrıca $\mathrm{AB}$ Komisyonu tarafindan 2016 Mayıs'ta kabul edilen ve 2018 Mayıs'ta yürürlüğe girecek olan Veri Korunmasına İlişkin Genel Düzenlemenin (The General Data Protection Regulation) kişisel verilere ilişkin yeni boyutlar açması muhtemel görülmektedir.

\section{Literatür Taraması}

Kişisel verilerin korunması son zamanlarda birçok ülkede önemli konuların başında gelmektedir. Bu nedenle kişisel verilerin korunması ile ilgili literatürde yer alan çalışmalar artış göstermektedir. Kişisel verilerin korunması ile ilgili Türkiye' de konu ile ilgili sınırlı sayıda çalışma bulunmasına karşın yurt dışında birçok çalışma bulunmaktadır. Söz konusu çalışmalar arasından seçilenlere Tablo 3 'te yer verilmiştir. 
Tablo 3: Seçilmiş Bazı Çalışmalar

\begin{tabular}{|c|c|c|c|}
\hline Yazar & Yıl & Kapsam & Sonuç \\
\hline $\begin{array}{l}\text { Ketizmen ve } \\
\text { Ülküderner }\end{array}$ & 2007 & Türkiye & $\begin{array}{l}\text { Kişisel verilerin korunmasına ve paylaşılmasına ilişkin standartlar } \\
\text { ve yöntemler belirlenmelidir. }\end{array}$ \\
\hline Özenç & 2007 & Türkiye & $\begin{array}{l}\text { Etkin ve verimli bir güvenlik kültürünün oluşturulması, kişisel } \\
\text { verilerin korunması ile ilgili düzenlemelerin yapılması, bilgi ve } \\
\text { iletişim teknolojilerinde uluslararası işbirliğine önem verilmesi } \\
\text { şarttır. }\end{array}$ \\
\hline Şimşek & 2008 & Türkiye & $\begin{array}{l}\text { Ulusal ve uluslararası mevzuat bağlamında kişisel verilerin } \\
\text { koruması ele alınmıştır. }\end{array}$ \\
\hline $\begin{array}{l}\text { Karaaslan ve } \\
\text { Koç }\end{array}$ & 2010 & Türkiye & $\begin{array}{l}\text { E-devlet sistemlerinde şifre olarak vatandaşlık numarası/nüfus } \\
\text { cüzdanı bilgilerinin kullanımında yaşanan sorunlar ve olası çözüm } \\
\text { yolları ele alınmıştır. E-devlet sistemleri tasarlanırken kişisel } \\
\text { verilerin mahremiyetinin ön planda tutulması, bu platformlardan } \\
\text { veri temin edilmediğinde şifrenin zorunlu olması gerektiği } \\
\text { belirtilmiştir. }\end{array}$ \\
\hline Kaya & 2011 & Türkiye & $\begin{array}{l}\text { AB mevzuatı çerçevesinde kişisel verilerin korunması ele alınmış } \\
\text { olup bu konudaki zorluklar olarak kişisel verilerin neler olduğunun } \\
\text { belirlenmesi ve bunların işlenmesi sayılmıştır. }\end{array}$ \\
\hline Kılınç & 2012 & Türkiye & $\begin{array}{l}\text { Kamu veya özel sektör tarafından işlenen veriler, hukuka uygun } \\
\text { olarak, belirli sürelerle, şeffaflık ilkesi çerçevesinde işlenmeli, } \\
\text { bireysel bu konuda bilgi alabilmeli, eksik veya yanlışlik varsa } \\
\text { düzeltilebilmelidir. }\end{array}$ \\
\hline Saadet & 2012 & Türkiye & $\begin{array}{l}\text { İletişimin gizliliğinin sınırlanması düzenlemeleri } \text { açıklık, } \\
\text { öngörülebilirlik gibi unsurları karşılayacak şekilde yeniden } \\
\text { düzenlenmelidir. }\end{array}$ \\
\hline Onur & 2013 & Türkiye & $\begin{array}{l}\text { Kişisel veri, verilerin işlenmesi, verilerin anonim hale getirilmesi, } \\
\text { verilerin saklanması kavramlarının karmaşaya mahal vermeyecek } \\
\text { şekilde yeniden tanımlanması gerektiği belirtilmiştir. Ayrıca } \\
\text { kişisel veriler ile ilgili bir düzenleyici denetleyici kurum ihtiyacı } \\
\text { belirtilmiştir. }\end{array}$ \\
\hline Karlıdağ & 2013 & kiye & $\begin{array}{l}\text { Kişisel verilerin korunmasına ilişkin } A B \text { ve } A B D \text { 'nin yaklaşımları } \\
\text { birbirine tezatlık teşkil etmektedir. Bu konuda } A B \text { devlete görev } \\
\text { atfederken ABD özel sektöre ve serbest piyasaya görev } \\
\text { yüklemektedir. }\end{array}$ \\
\hline Manav & 2015 & Türkiye & $\begin{array}{l}\text { İş mevzuatında işçinin kişisel verilerinin korunması konusunda } \\
\text { yeterli düzenleme bulunmadığı, sorun yaşanması halinde genel } \\
\text { hükümlere göre çözüm arandığı için kişilik haklarını korumaya } \\
\text { yeterli olmadığı, dolayısı ile özel düzenleme yapılması gerektiği } \\
\text { sonucuna ulaşılmıştır. }\end{array}$ \\
\hline Turan & 2015 & Türkiye & $\begin{array}{l}\text { İnternet ve elektronik ortamlarda riskler artmakta olup süreklilik } \\
\text { perspektifi içinde teknolojik, yasal, kolluk ve idari tedbirler } \\
\text { alınmalıdır. }\end{array}$ \\
\hline $\begin{array}{l}\text { Barnard-Wills } \\
\text { vd. }\end{array}$ & 2016 & B Ülkeleri & $\begin{array}{l}\text { Veri koruma kurumları arasında işbirliğinin sağlanmasında, } \\
\text { iletişim, bilgi paylaşımı, uyarı araçları ve taleplerin } \\
\text { yapılandırılması ilişkin sistemler genel olarak faydalı ve } \\
\text { işbirliğini engellemeyen araçlar olarak görülmektedir. }\end{array}$ \\
\hline
\end{tabular}




$\begin{array}{cccc}\text { Yazar Yıl Kapsam } & \text { Sonuç }\end{array}$

$\begin{array}{llll}\text { Bingöl ve } & & & \\ \text { Koruyan } & & \text { Türkiye }\end{array}$

Avrupa Birliği Adalet Divanı tarafından Avrupa Komisyonunun vermiş olduğu güvenli liman kararının geçersizliğine karar vermiştir. Bu nedenle Türkiye'de KVKK'da belirtilen kişisel verilerin yurt dışına aktarılması uygulamasının etkin bir şekilde yürütülebilmesi için Kişisel Verileri Koruma Kurumu tarafından Avrupa Birliğindeki süreç yakından takip edilmelidir.

Kişisel verilerin korunmasına ilişkin sistemlerin işlerliği önemli Türkiye tartıșma konularından birini olușturmaktadır. Tartıșmalar kișisel verilerin korunmasının etkinliği, insan haklarına ve bireysel özgürlüklere uygunluğu hususlarında yoğunlaşmaktadır.

Turan $2016 \quad$ Türkiye

Veri sorumlusu kurumların yayınlanacak yönetmelik çerçevesinde görev ve sorumlulukları yerine getirmeleri, mevzuata uyuma dikkat ve özen göstermelidir.

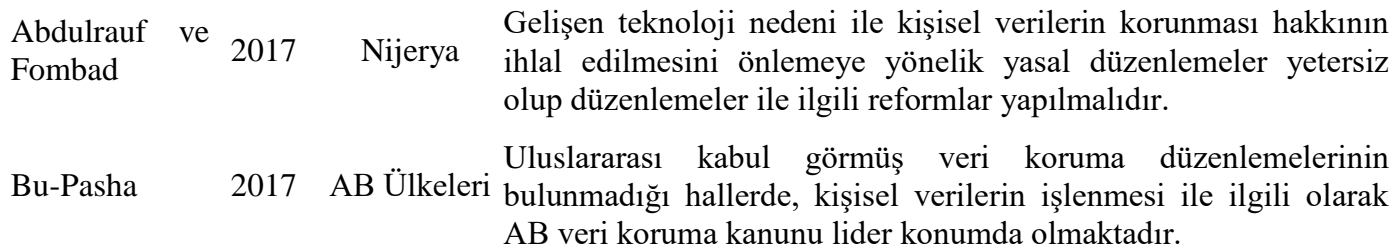

Chua vd. 2017 Malezya Kamu kuruluşlarına kıyasla özel kuruluşlar kişisel verilerin korunması kanunu ile daha yüksek uyuma sahiptirler.

$\begin{array}{llcl}2017 & \text { İngiltere } & \begin{array}{l}\text { Ekonomik Bölgesi’ndeki Yasal Veri Koruma Otoriteleri, Avrupa } \\ \text { Veri Koruma Kanunu'nu katı şekilde yorumlayarak } \\ \text { uyarlamışlardır. }\end{array} \\ \text { Hoel ve Chen 2017 Norveç } & \begin{array}{l}\text { Verilerin korunması ve gizlilik, politik, kültürel, ekonomik ve } \\ \text { diğer söylemlerden zamanla oluşan yasal düzenlemelere } \\ \text { dayanmaktadır. }\end{array}\end{array}$

Lubis vd. 2017 Malezya Gizlilik endişeleri ve algılanan fayda kişisel verilerin korunmasını önemli derecede etkilemektedir.

2018 yılında yürürlüğe girecek yeni düzenlemede amaç Preite vd. $2017 \quad$ İtalya uyumluluğu ilkesi, daha önceden toplanan ve kullanılabilir kişisel verilerin, veri sahiplerinin açık rızası olmadan kullanılabilmesine yönelik yorumlanmıştır.

Raab ve $2017 \quad$ Veri koruma otoritelerinin sahip olması gereken bilgi teknolojileri

Szekely 2017 AB Ülkeleri ile ilgili ideal bir durum yoktur, sürekli öğrenme hali söz konusudur.

Tikkinen-Piri 2017 Son yıllarda şirketlerin faaliyetlerinde kişisel veri kullanımına vd. yönelik artan ilgilerine paralel olarak gizlilik konusundaki düzenlemeler dönüşmektedir.

Van den 2017 AB Ülke. AB vatandaşlarının gizliliğe yönelik yaklaşımlarında güvenlik Broek vd. 2017 AB Ülkeleri hususu temel teşkil etmekte ve kişisel bilgileri toplayanların ve işleyenlerin kamu ya da özel sektör olması önem taşımaktadır. 
4. Kişisel Verilerin İşlenebileceği Durumlar ve Kişisel Verilerin Korunmasına İlişkin Mevzuat

Başta KVKK olmak üzere ulusal ve uluslararası mevzuatta yer alan düzenlemeler kapsamında kural olarak kişisel verilerin işlenmesi yasaktır (AB, 1995: madde 8; KVKK, 2016: madde 5). Bununla birlikte hayatın olağan akışı gereği bazı durumlarda kişisel verilerin işlenmesi gerekebilmektedir. Kişisel verilerin işlenmesi yasak kuralına karşın bir istisna olarak değerlendirilmektedir. Bu kısımda öncelikle kişisel verilerin işlenebileceği durumlar, sonrasında ise kişisel verilerin korunmasına ilişsin Türkiye'deki ve AB'deki mevzuat durumuna yer verilecektir.

\subsection{Kişisel Verilerin İşlenebileceği Durumlar}

İstisnai olarak kişisel verilerin işlenebilmesi belirli durumlarda olabilmektedir. Bunun birinci şartı veri sahibinin açık şekilde muvafakat vermesi yani verilerinin işlenmesine rıza göstermesidir (KVKK, 2016: madde 5). Bununla birlikte veri sahibinin zımni olarak muvafakat göstermesi mevzuat açısından yeterli görülmemektedir (AB, 1995: madde 8/2a). Diğer taraftan "açık" terimi net bir şekilde ifade edilmemiş olup bu konuda farklı yorumlar yapılmaktadır.

Kişisel verilerin işlenmesinin ikinci istisnası kamu hukuku yükümlülüklerine uyulması amaciyla verilerin işlenmesidir. Ulusal hukuk sistemlerinin yeterli güvence sağlaması ve yetki vermesi halinde kamu hukuku alanında yükümlülükleri yerine getirmek ve hakları korumak için zorunlu ise kişisel veriler işlenebilir (AB, 1995: madde 8/2b). Dolayısıyla ulusal mevzuat tarafindan belirli yükümlülüklerin yerine getirilmesi zorunlu kılınıyorsa bu kapsamda kişisel veriler işlenebilmektedir.

Kişisel verilerin işlenmesinin üçüncü istisnası veri sahibinin hayati çıkarlarının korunmasıdır. Veri sahibi fiziki ya da hukuki nedenlerle muvafakat veremeyecek durumda ise, veri sahibinin veya bir başka kişinin hayati çıkarlarının korunması için zorunlu olduğu durumlarda kişisel veriler işlenebilmektedir (AB, 1995: madde $8 / 2 \mathrm{c}$ ). Bu istisna genel hatları itibarı ile insan yaşamının tehdit eden durumların varlığı halinde uygulanabilmektedir (Bainbridge, 2005: 100; Singleton, 2006: 571).

Kişisel verilerin işlenmesinin dördüncü istisnası özel hukuk tüzel kişilerinin faaliyetleri çerçevesinde kişisel verilerin işlenmesidir. Uygun güvencelerin sağlanması kaydıyla siyasi, felsefi, dini veya sendikal amaç taşıyan bir vakfın, derneğin ve benzeri diğer kâr amacı gütmeyen kuruluşların meşru faaliyetleri sırasında kişisel veriler işlenebilir. Böyle bir durumda veri işlemenin sadece bu kuruluşların üyeleri veya amaçları için bu kuruluşlarla düzenli irtibat halinde olan kişiler hakkında olması ve veri sahiplerinin muvafakati olmaksızın verilerin üçüncü kişilere açıklanmaması şartı aranır (AB, 1995: madde 8/2d). 
Uluslararası Ekonomi ve Yenilik Dergisi, 4 (1) 2018, 1-18

Kişisel verilerin işlenmesinin beşinci istisnası kişisel verilerin kamuya açıklanmış olmasıdır. Veri sahibi tarafından açık şekilde kamuya açıklanan kişisel veriler işlenebilir (AB, 1995: madde 8/2e). Diğer bir ifade ile veri sahibi tarafından iradi olarak kamuya açıklanan/kamu malı haline gelen bilgiler kişisel veri dahi olsa işlenebilir (KVKK, 2016: madde 5). Kamuya açıklanan bilgiler veri sahibi tarafından iradi olarak paylaşılmamışsa, iradesi dışında yayılmışsa bu durumda kişisel veriler işlenemez.

Kişisel verilerin işlenmesinin altıncı istisnası hukuki iddiaları tesis etme, uygulama ve savunma ile ilgilidir. Dolayısı ile hukuki iddiaları tesis etme, uygulama ve savunma için zorunlu ise kişisel veriler işlenebilmektedir (AB, 1995: madde 8/2e). Örnek olarak avukatların, müvekkillerinin talimatlarını yerine getirirken yaptığı faaliyetlerin çoğu bu kapsama örnek teşkil etmektedir (Carey, 2009: 87; Kaya, 2011: 330).

Kişisel verilerin işlenmesinin yedinci istisnası sağlı gereklilikleridir. Önleyici tıp, tıbbi teşhis ve tanı, bakım ve tedavi sunma, sağlık hizmetlerinin yönetimi amaçları için zorunlu ise kişisel veriler işlenebilmektedir. Ancak ulusal hukuka veya mesleki gizlilik yükümlülüklerine tabi sağlık personelleri (doktor, hemşire, ebe, dişçi, gözlükçü, eczacı vb.) tarafından sağlık gereklilikleri ile kişisel verilerin işlenebilir (AB, 1995: madde 8/3).

Kişisel verilerin işlenmesinin sekizinci istisnası suçlar, mahkûmiyetler ve güvenlik tedbirleri kapsamında kişisel verilerin işlenmesidir (AB, 1995: madde 8/5). Bu gibi durumlarda resmi kurumlar tarafından kişisel veriler izlenebilir.

Kişisel verilerin işlenmesinin son istisnası ise ülkelerin yeni bir istisna alanı tanımlamasıdır (AB, 1995: madde 8/4). Ülkeler uygun güvenceler öngörmek suretiyle önemli/üstün kamu yararı gerekçesiyle ulusal mevzuatlarında düzenleme yaparak ek istisnalar tanımlayabilmektedir. Kişisel verilerin işlenmesine yönelik istisnalar içinde en önemli istisna bahsedilen bu son istisnadır. Nitekim bu kurala göre ülkeler kişisel verilerin korunmasına yönelik yeni istisnalar koyabilmektedir.

\subsection{Türkiye'de Kişisel Verilerin Korunması Mevzuatı}

Kişisel verilerin korunmasına yönelik düzenlemelerin temelini anayasalar, uluslararası anlaşma ve sözleşmeler oluşturmaktadır. Ayrıca kişisel verilerin korunmasına ilişkin detayları belirlemek üzere konu ile ilgili kanun, yönetmelik, tebliğ gibi ikincil düzenlemeler de mevzuatta yer almaktadır. Bu kısımda kişisel verilerin korunması bağlamında bankacılıkla ilgili olan düzenlemelerine yer verilecektir.

\subsubsection{Birincil Mevzuat}

Kişisel verilerin korunması ile ilgili düzenlemelerin temelini Anayasa oluşturmaktadır. Anayasa'nın özel hayatın gizliliği başlıklı maddesinde "Herkes, kendisiyle ilgili kişisel verilerin korunmasını isteme hakkına sahiptir. Bu hak; kişinin kendisiyle ilgili kişisel veriler hakkında bilgilendirilme, bu verilere erişme, 
bunların düzeltilmesini veya silinmesini talep etme ve amaçları doğrultusunda kullanılıp kullanılmadığını öğrenmeyi de kapsar. Kişisel veriler, ancak kanunda öngörülen hallerde veya kişinin açık rızasıyla işlenebilir. Kişisel verilerin korunmasına ilişkin esas ve usuller kanunla düzenlenir" hükmü yer almaktadır (Anayasa, 1982: madde 20). Bu madde tüm vatandaşların kişisel verilerin korunmasını bir hak olarak kabul ederken ikincil mevzuatta yer alan tüm düzenlemelerin dayanağını da teşkil etmektedir.

Kişisel verilerin korunması ile ilgili bir diğer düzenleme 17.03.2016 tarihli Resmi Gazetede yayınlanan 108 sayılı Avrupa Konseyi Sözleşmesi'dir. Bu sözleşme kişisel verilerin korunmasına yönelik $\mathrm{AB}$ standartları kapsamında düzenlemeler getirmektedir. Ayrıca 05.05.2016 tarihli Resmi Gazetede yayınlanan Kişisel Verilerin Otomatik İşleme Tabi Tutulması Karşısında Bireylerin Korunması Sözleşmesine Ek Denetleyici Makamlar ve Sınır aşan Veri Akışına İlişkin Protokol bu sözleşmeye ek olarak yürürlüğe girmiştir.

\subsection{2. İkincil Mevzuat}

İkincil mevzuat kapsamında kişisel verilerin korunması ile ilgili en önemli düzenleme 07.04.2016 tarihli Resmi Gazetede yayınlanan Kişisel Verilerin Korunması Kanunu'dur. Anayasa'da temel bir hak olarak düzenlenen kişisel verilerin korunması konusunda tarafların hak ve sorumlulukları KVKK' da tanımlanmıştır. KVKK' da kişisel verilerin korunmasına yönelik olarak tanımlar, genel ilkeler, kişisel verilerin işlenme şartları, özel nitelikli kişisel verilerin işlenme şartları, kişisel verilerin silinmesi, yok edilmesi, anonim hale getirilmesi, yurt içinde veya yurt dışına aktarılması, tarafların hak ve yükümlükleri, suçlar ve kabahatlere uygulanacak cezalar ile Kişisel Verileri Koruma Kurumu'na ilişkin hükümlere yer verilmiştir.

İkincil mevzuatta kişisel verilerle ilgili bir diğer düzenleme Türk Ceza Kanunu'dur (TCK). TCK'da kişisel verilerin korunması perspektifinden kişisel verilerin kaydedilmesi, verilerin hukuka aykırı olarak paylaşılması veya ele geçirilmesi, söz konusu durumların nitelikli şekilde gerçekleşmesi, verilerin yok edilmemesi, tüzel kişilere ilişkin tedbirler, bilişim sistemlerine sızılması, bilişim sistemlerinin engellenmesi, bozulması, verilerin yok edilmesi veya değiștirilmesi ile ilgili ceza maddelerine yer verilmiştir (TCK, 2004: madde 135-136-137-138139-140-243-244).

Yukarıda bahsedilen KVKK ve TCK'nın yanı sıra bazı kanunlarda kişisel verilerin korunması ile ilişkili düzenlemeler yer almaktadır. Bunlar özet olarak aşağıda gibidir;

- $\quad$ Türk Medeni Kanunu'nda (TMK) kişiliğin korunması ile ilgili hükümler (TMK, 2001: madde 24-25),

- $\quad$ İş Kanunu'nda (İK) işçi özlük dosyası ile ilgili hüküm (İK, 2003: madde 75), 
BK'da sırların saklanması, sırların açıklanması ve risk merkezi ile ilgili hükümler (BK, 2005: madde 73, 159, Ek 1),

- Banka Kartları ve Kredi Kartları Kanunu'nda (BKKKK) kart çıkarma ve buna ilişkin yükümlülükler, bilgilerin saklanması, sırların saklanması, bilgi güvenliği yükümlülügüne aykırı davranılması ile ilgili hükümler (BKKKK, 2006: madde 8-23-31-39).

- Türk Borçlar Kanunu'nda (TBK) işçinin kişiliğinin korunması ile ilgili hüküm (TBK, 2011: madde 419),

- $\quad$ Türk Ticaret Kanunu'nda (TTK) haksız rekabet ve çek ile ilgili hükümler (TTK, 2011: madde 55-780).

Yukarıda özet olarak yer verilen düzenlemeler kişisel verilerin çeşitli taraflarla paylaşımına ilişkin düzenlemeler içermektedir. Bahsedilen mevzuatların dışında Bilgi Edinme Hakkı Kanunu, Adli Sicil Kanunu vb. gibi düzenlemelerde de kişisel verilerin korunması ile ilgili düzenlemeler yer almakta olup bankacılık ile doğrudan ilgili olmadığından burada yer verilmemiştir.

\subsection{AB'de Kişisel Verilerin Korunması}

Kişisel verilerin korunması ile ilgili olarak çeşitli ülkelerin ve birliklerin öncü oldukları görülmektedir. Şüphesiz ki bu kuruluşların başında Birleşmiş Milletler gelmektedir. 1948 yılında genel kurul tarafindan kabul edilen İnsan Hakları Evrensel Bildirgesi kişisel verilerin korunmasının temelini oluşturmaktadır. Birleşmiş Milletlerden sonra öncü birliklerin başında AB gelmektedir.

AB 1950 yılında kabul ettiği ve 1953 yılında yürürlüğe giren İnsan Haklarının Korunmasına ve Temel Özgürlüklere İlişsin Avrupa Konvansiyonu, AB' de kişisel verilere ilişkin çalışmaların temellerini oluşturmuştur. Sonrasında ise 1981 tarihli Bireylerin Korunması Konvansiyonu, 1995 tarihli Verilerin Korunmas1 Direktifi, 2002 tarihli Gizlilik ve Elektronik İletişime İlişkin Direktif ile mevzuat çerçevesini iyileştirmeye çalıştırmıştır. Son olarak AB Komisyonu tarafindan 2016 Mayıs'ta kabul edilen ve 2018 Mayıs’ta yürürlüğe girecek olan Veri Korunmasına İlişkin Genel Düzenleme kişisel verilerin korunmasına ilişkin önemli bir gelişmedir.

\section{Türk Bankacılık Sektörü Üzerine Bir Değerlendirme ve Bankalarda Uyum İçin Yapılması Gerekenler}

Mevzuatta kişisel verilerin korunması ile ilgili çeşitli düzenlemeler yer almakla birlikte bankacılık açısından KVKK doğrudan etki oluşturmaktadır. Çünkü KVKK' da kişisel verilerin işleme amaçlarını ve vasıtalarını belirleyen, veri kayıt sisteminin kurulmasından ve yönetilmesinden sorumlu olan gerçek veya tüzel kişi veri sorumlusu olarak tanımlanmıştır. $\mathrm{Bu}$ tanım çerçevesinde bankalar veri sorumlusu addedilmektedir.

Bankalar veri sorumlusu olarak kişisel verisi işlenen gerçek kişilerin açık rızası olmaksızın kişisel verileri işleyemezler (KVKK, 2016: madde 5/1). Ancak veri 
sorumlusu bankanın hukuki yükümlülüklerini yerine getirmek için zorunlu olması veya ilgili kişinin temel hak ve özgürlüklerine zarar vermemek kaydıyla, veri sorumlusunun meşru menfaatleri için zorunlu olması halinde kişisel veriler işlenebilir (KVKK, 2016: madde 5/2).

KVKK veya diğer kanunlara uygun olarak işlenen kişisel veriler, işlenmeyi gerektiren sebeplerin ortadan kalkması halinde ilgili kişinin talebi üzerine veya veri sorumlusu tarafindan resen silinir, yok edilir veya anonim hale getirilir (KVKK, 2016: madde 7/1).

Diğer taraftan KVKK ile veri sorumlusu bankalar hakkında getirilen en önemli yükümlülük kişisel verilerin elde edilmesinden önce veya en geç elde edilme sırasında aydınlatma yapılmasıdır (KVKK, 2016: madde 10). Ayrıca veri sorumlusu kişisel verilerin hukuka aykırı işlenmesini ve erişilmesini önlemek ve kişisel verileri muhafaza etmek, gerekli denetimleri yapmak/yaptırmak zorundadır (KVKK, 2016: madde 12).

Yukarıda KVKK kapsamında veri sorumlusu olarak tanımlanan bankalara getirilen yükümlülüklerin bir kısmı özetlenmiştir. Bunun yanı sıra kanunda başka yükümlülükler de bulunmaktadır. Söz konusu hükümler açısından KVKK'ya bakıldığında bankaların yerine getirmesi gereken temel yükümlülük kişisel verilerin işlenmesi öncesinde bireylerin bilgilendirilmesi ve gerekçesi ortadan kalkan verilerin imha edilmesidir. Dolayısıyla bankalar KVKK'ya uyum sağlayabilmek için aşağıdaki süreçlerini gözden geçirmelidir;

- Yeni müşteri kabul süreçleri,

- Bireysel müşterilerin kaydolma süreçleri,

- Tüzel müşterilerin kaydolma süreçleri (gerçek kişi ortaklar ve yetkililer açısından),

- Finansal kurumların kaydolma süreçleri (gerçek kişi ortaklar ve yetkililer açisından),

- Mevcut müşterilerin değerlendirilmesi süreçleri,

- Veri analitiği ve raporlama süreçleri,

- İç kontrol, iç denetim ve uyum süreçleri.

Ayrıca bankaların 07.04.2016 tarihinden önce işledikleri kişisel verileri 07.04.2018 tarihine kadar KVKK ile uyumlu hale getirmesi gerekmektedir (KVKK, 2016: geçici madde 1). Söz konusu uyumun sağlanmasında iki seçenek söz konusudur. $\mathrm{Bu}$ seçenekler müşterilerden kişisel verilerinin işlenmesine yönelik açık rıza beyanı (muvafakatname) alınması veya kişisel verilerin silinmesi/yok edilmesi/anonim hale getirilmesidir. İlerleyen süreçte kişisel verilerin korunmasına yönelik başta BDDK ve Kişisel Verileri Koruma Kurumu olmak üzere DDK'lar tarafindan denetim yapılması söz konusu olabileceğinden dolayı bankaların kanıtlanabilir belgelendirme/arşivleme yapıları oluşturması kritik bir husustur. 
KVKK'ya uyum çalışmaları kapsamında önemli hususlardan bir diğeri ise bankanın uyum çalışmalarını gözetecek bir üst düzey yöneticinin belirlenmesidir. Her ne kadar KVKK'da bu yönde bir hüküm yer almasa da bankada işin sahiplenilmesi ve üst düzey gözetimi açısından faydalı olacaktır. KVKK konusu aynı zamanda bir uyum konusu olması nedeniyle belirlenecek bu üst düzey yönetici iç kontrol, uyum, iç denetim, hukuk gibi bölümlerin üst düzey yöneticileri olabilir.

Bankalar KVKK kapsamında tüm iç düzenlemelerini yaptığını ve mevzuata uyum sağladıklarını düşünebilirler. Bu noktada bankaların iç kontrol ve iç denetim birimleri devreye girmelidir. Çeşitli mevzuat düzenlemeleri kapsamında bankaların yürüttükleri faaliyetler KVKK kriterleri ve gereklilikleri doğrultusunda gözden geçirilmeli, müşterilere ait kişisel verilerin işlenmesi, depolanması, çeşitli kişiler tarafından erişilmesi gibi hususlar iç kontrol ve iç denetim çalışmalarının kapsamına dâhil edilmelidir.

Bankaların gerçekleştirmesi gereken faaliyetler açısından yukarıda bahsedilenler arasında en önemli husus kişisel verilerin gizliliğinin sağlanmasıdır. Bu ancak banka bilgi teknolojileri altyapısının ve iş süreçlerinin KVKK gereklilikleri bağlamında düzenlenmesi ve banka personelinin eğitimi ile mümkün olabilir. Banka personelleri görevlerinin gerektirdiği kadar kişisel verilere ulaşabilmelidir. Böylece herhangi bir suiistimale mahal verilmeyecektir. Dolayısı ile personelin KVKK gereklilikleri hakkında eğitilmesi ve bu gerekliliklerin banka içinde periyodik olarak duyurulması önem arz etmektedir.

Sonuç olarak kişisel verilerin korunması bankalar ve müşteriler açısından kritik bir husus olup mevzuata uyumsuzluk halinde bundan hem bankalar hem de müşteriler ciddi zararlar görebilecektir. Nitekim KVKK'da detayları değişmekle birlikte hapis ve 1 milyon TL'ye varan cezalar öngörülmektedir. Bu nedenle bankalarda kişisel verilerin korunması ile ilgili iç kontrol ve denetim mekanizmaları ihdas edilmeli, banka uygulamaları düzenli bir şekilde izlenmeli, gerektiğinde idari ve adli işlemler tesis edilmelidir. Mevzuata tam uyum sağlanmaması halinde bankalar ciddi yaptırımlara maruz kalabileceklerdir.

\section{Sonuç}

Kişisel verilerin korunması oldukça önemli, nazik ve zor bir konudur. AB Direktifinde kişisel verilerin ayrı bir madde olarak düzenlenmesi ve farklı bir statüye tabi tutulması konunun uluslararası açıdan önemini; 2016 yılında KVKK'nın yayınlanması ise konunun Türkiye açısından önemini ortaya koymaktadır.

KVKK bağlamında bankaların veri sorumlusu olarak tanımlandığı dikkate alındığında KVKK bünyesinde müşteriler hakkında birçok kişisel bilgi tutan bankaları yakından ilgilendirmektedir. Nitekim KVKK kişisel verilerin toplanması, işlenmesi, depolanması ve silinmesi ile ilgili kurallar ortaya koymakta, kuralları ihlal eden kişi ve kurumlara çeşitli para ve hapis cezaları 
öngörmektedir. Ayrıca zarara uğrayan kişilerin banka ve banka personeli aleyhine adli yollara başvurabileceği de unutulmamalıdır.

Diğer taraftan günümüzde bankacılık kârlılık, müşteri memnuniyeti ve mevzuata uyum odaklı bir yapı üzerine kurulu hale gelmiştir. Rekabet Kurumu, Gümrük ve Ticaret Bakanlığ 1 , Sermaye Piyasası Kurulu gibi düzenleyici-denetleyici otoriteler tarafından bankalara milyar liralara yaklaşan cezaların verildiği, KVKK'da yüklü miktarda para cezaları öngörüldüğü ve ilerleyen süreçte Kişisel Verileri Koruma Kurumu tarafından söz konusu cezaların uygulanabileceği dikkate alındığında müşteri şikâyetlerinin önlenmesi, kârlılığın sürdürülebilmesi ve muhtemel davaların önüne geçilebilmesi açısından diğer düzenlemelerle birlikte KVKK çok önemli bir noktada yer almaktadır.

Gelinen noktada bankaların KVKK' ya uyum sağlaması oldukça önem taşıyan bir konu olarak ön plana çıkmaktadır. Bu çalışmada bankaların KVKK'ya uyum konusunda yerine getirmesi gereken faaliyetlere yer verilmiştir. Banka bilgi teknolojileri altyapısının ve iş süreçlerinin KVKK gereklilikleri bağlamında düzenlemesi, banka personelinin eğitimi, personellerin görevlerinin gerektirdiği kişisel verilere erişebilmesi, KVKK gerekliliklerinin banka içinde periyodik olarak duyurulması bankalarca gerçekleştirilmesi gereken önerilerin başında gelmektedir. Söz konusu öneriler KVKK'ya uyum sağlanması hususunda bankalara yardımcı olacaktır.

Bankaların 07.04.2016 tarihinden önce işledikleri kişisel verileri 07.04.2018 tarihine kadar KVKK ile uyumlu hale getirmeleri bir zorunluluk olduğundan bankaların muhtemel yaptırımları dikkate alarak uyum konusunda azami hassasiyet göstermeleri ve söz konusu tarih gelmeden çalışmalarının tamamlamaları yerinde olacaktır. Türkiye'de bankalara BDDK, SPK, RK, GTB gibi DDK'lardan mevzuata uyumsuzluk nedeniyle milyon liralar düzeyinde cezalar kesildiği dikkate aldığında KVKK'ya uyum konusu daha hayati bir hal almaktadır. $\mathrm{Bu}$ nedenle bankalar kişisel verilerin korunmasına azami dikkat etmeli, istisnasız ve gecikmesiz olarak KVKK mevzuatının bütün gerekliliklerine uymalıdırlar. Bunun sağlanması için banka uygulamaları düzenli bir şekilde izlenmeli, kişisel verilerin korunmasına yönelik faaliyetler bankaların iç kontrol ve iç denetim birimleri tarafından denetlenmeli, gerektiğinde idari ve adli işlemler tesis edilmelidir. Denetim sonuçları bankaların yönetim kurulları, denetim komiteleri, genel müdürleri ve KVKK faaliyetlerinin gözetiminden sorumlu üst yöneticinin yanı sıra BDDK, SPK, Kişisel Verileri Korumu Kurumu gibi DDK'lar tarafından da yakından takip edilmelidir. Mevzuata tam uyum sağlanmaması halinde bankaların ciddi yaptırımlarla karşı karşıya kalacağı unutulmamalıdır.

Son olarak Türkiye'de bankaların KVKK'ya uyum sağlama yükümlülüğü bulunmakla birlikte ülkeler arasında kişisel verilerin tanımı ve sınıflandırılması ile farklılıklar bulunduğu unutulmamalıdır. Küreselleşmenin ve teknolojik gelişmelerin de etkisiyle birlikte ülkeler arasındaki iletişimin ve iş birliğinin artması sonucunda yakın gelecekte kişisel verilerin tanımlanması, istisnalar ve ne 
şekilde işlenip depolanacağı, hangi durumlarda açıklanabileceği ve paylaşılabileceği gibi hususlarda yeknesaklık sağlanması adına bazı gelişmelerin yaşanması beklenmektedir. Dolayısıyla bankaların söz konusu değişiklik süreçlerini yakından takip etmesi önerilmektedir.

Türkiye' de bankacılık sektöründe kişisel verilerin korunmasına yönelik çalışma bulunmaması nedeni ile kişisel verilerin korunmasını kavramsal olarak ele alan bu çalışma ile birlikte konu literatüre kazandırılmaktadır. Sonraki çalışmalarda anket veya banka yöneticileri ile görüşmeler yapılmak sureti ile ampirik bulguları da içeren çalışmaların bankacılık sektörüne yönelik gerçekleştirilebileceği değerlendirilmektedir.

\section{Kaynakça}

Abdulrauf, L. A. ve Fombad, C.M. (2017), "Personal Data Protection in Nigeria: Reflections on Opportunities, Options and Challenges to Legal Reforms", Liverpool Law Review, 38(2), 105-134.

AB. (1995), "Directive 95/46/EC of the European Parliament and of the Council of 24 October 1995 on the Protection of Individuals with Regard to the Processing of Personal Data and on the Free Movement of Such Data", OJL 281, 23.11.1995, 31-50.

Aksoy, H. C. (2010), Medeni Hukuk ve Özellikle Kişilik Hakkı Yönünden Kişisel Verilerin Korunması, Ankara: Çakmak Yayınevi.

Anayasa. (1982), 2709 sayılı, 07.11.1982 tarihli ve 17863 mükerrer sayılı Resmi Gazete.

Bainbridge, D. (2005), "Data Protection". Second Edition, St Albans: XPL Publishing.

Barnard-Wills, D., Chulvi, C. P. ve De Hert, P. (2016), "Data Protection Authority Perspectives on the Impact of Data Protection Reform on Cooperation in the EU", Computer Law \& Security Review, 32(4), 587-598.

BKKKK. (2006), 5464 sayıl1, 01.03.2006 tarihli ve 26095 sayılı Resmi Gazete.

BK. (2005), 5411 sayılı, 01.11.2005 tarihli ve 25983 say1lı Resmi Gazete.

Bingöl, F. I. ve Koruyan, K. (2016), Kişisel Verilerin Yurt Dışı Sunuculara Aktarılmasının Bilişim Sistemleri Çerçevesinde Türk Ve Avrupa Hukuku Açısından İncelenmesi, İzmir: 3. Uluslararası Yönetim Bilişim Sistemleri Konferans1.

Bu-Pasha, S. (2017), "Cross-Border Issues Under EU Data Protection Law With Regards to Personal Data Protection", Information \& Communications Technology Law, 26(3), 213-228.

Carey, P. (2009), Data Protection: A Practical Guide to UK and EU Law, Oxford: Oxford University Press. 
Chua, H. N., Herbland, A., Wong, S. F. ve Chang, Y. (2017), "Compliance to Personal Data Protection Principles: A Study of How Organizations Frame Privacy Policy Notices"; Telematics and Informatics, 34(4), 157-170.

Dinçer, H., Hacıoğlu, Ü. ve Yüksel, S. (2016), "Performance Assessment of Deposit Banks with CAMELS Analysis using Fuzzy ANP-MOORA Approaches and an Application on Turkish Banking Sector", Asian Journal of Research in Business Economics and Management, 6(2), 32-56.

Dülger, M. V. (2015), "Kişisel Verilerin Korunması Kanunu ve Türk Ceza Kanunu Bağlamında Kişisel Verilerin Ceza Normlarıyla Korunması”, İstanbul Medipol Üniversitesi Hukuk Fakültesi Dergisi, 3(2), 101-167.

Erdos, D. (2017), “Beyond 'Having a Domestic?' Regulatory Interpretation of European Data Protection Law and Individual Publication", Computer Law \& Security Review, 33(3), 275-297.

Hoel, T. ve Chen, W. (2017), "Towards Developing an Educational Maxim for Privacy and Data Protection in Learning Analytics", http://hoel.nu/files/ECTEL_EthicsPrivacy_workshop_paper_2017-09-12.pdf (Erişim: 30.09.2017).

İK. (2003), 4857 sayıl1, 10.06.2003 tarihli ve 25134 sayılı Resmi Gazete.

Karaarslan, E. ve Koç, S. (2010), Vatandaşlık Numarası Bazlı E-Devlet Sistemlerinde Kişisel Veri Mahremiyeti Durum Saptamas1, İzmir: Bilişim Hukuk Kurultayı, 1-8.

Karlıdağ, S. (2013), "Ekonomi Politik Açıdan Kişisel Verilerin Korunması"; Amme İdaresi Dergisi, 46(1), 127-152.

Kaya, C. (2011), “Avrupa Birliği Veri Koruma Direktifi Ekseninde Hassas (Kişisel) Veriler ve İşlenmesi”, İstanbul Üniversitesi Hukuk Fakültesi Mecmuast, 69(1-2), 317-334.

Ketizmen, M. \& Ülküderner, Ç. (2007), E-Devlet Uygulamalarında Kişisel Verilerin Korun(ma)ması, XII. Türkiye'de İnternet Konferansı.

Kilınç, D. (2012), “Anayasal Bir Hak Olarak Kişisel Verilerin Korunması”, Ankara Üniversitesi Hukuk Fakültesi Dergisi, 61(3), 1089-1169.

KVKK. (2016), 6698 sayıl1, 07.04.2016 tarihli ve 29677 sayılı Resmi Gazete.

Küzeci, E.(2010), Kişisel Verilerin Korunması, Ankara: Turhan Kitabevi.

Lloyd, I. J. (2008), Information Technology Law, Fifth Edition, Oxford: Oxford University Press.

Lubis, M., Kartiwi, M. ve Zulhuda, S. (2017), "Privacy and Personal Data Protection in Electronic Voting: Factors and Measures", Telkomnika, 15(1), 512-521. 
Manav, A. E. (2015), “İş İlişkisinde İşçinin Kişisel Verilerinin Korunması”, Gazi Üniversitesi Hukuk Fakültesi Dergisi, 19(2), 95-136.

Onur, A. (2013), GSM Sektörüne Yönelik Düzenlemeler ve Etkileri: Kişisel Veri Koruması Bazında. İstanbul Bilgi Üniversitesi, Sosyal Bilimler Enstitüsü, Bilişim ve Teknoloji Hukuku Anabilim Dalı, Yüksek Lisans Tezi, İstanbul.

Özenç, K. (2007), Bilgi ve İletișim Teknolojilerinde Kișisel ve Kurumsal Bilgi Güvenliğinin Sağlanması, 183-190, 13-14 Aralık, Ankara: Uluslararası Katılımlı Bilgi Güvenliği ve Kriptoloji Konferansı, Bildiriler Kitabı.

Preite, F., Salardi, S., Gesuita, R., Villani, S. Trerotoli, P., Guardabasso, V. \& Zambon, A. (2017), "The New European Regulation on Personal Data Protection: Significant Aspects for Data Processing for Scientific Research Purposes", Epidemiology, Biostatistics and Public Health, 14(2), doi: $10.2427 / 12286$.

Raab, C. \& Szekely, I. (2017), "Data Protection Authorities and Information Technology", Computer Law \& Security Review, (33), 421-433.

Sevimli, A. (2011), "Veri Koruma Hukuku İlkeleri Işığında Türk Borçlar Kanunu Madde 419”, Sicil İş Hukuku Dergisi, 6(24), 120-139.

Singleton, S. (2006), Tolley's Data Protection Handbook, 4th Edition, London: Lexis NexisButterworths.

Şimşek, O. (2008), Anayasa Hukukunda Kişisel Verilerin Korunması, 1. Baskı, İstanbul: Beta Yayınları.

Tikkinen-Piri, C., Rohunen, A. \& Markkula, J. (2017), "EU General Data Protection Regulation: Changes and Implications for Personal Data Collecting Companies", Computer Law \& Security Review, doi: 10.1016/j.clsr.2017.05.015.

TBK. (2011), 6098 sayılı, 04.02.2011 tarihli ve 27836 sayılı Resmi Gazete.

TCK. (2004), 5237 sayıl1, 12.10.2004 tarihli ve 25611 say1lı Resmi Gazete.

TMK. (2001), 4721 sayıl1, 08.12.2001 tarihli ve 24607 sayılı Resmi Gazete.

TTK. (2011), 6102 say1l1, 14.02.2011 tarihli ve 27846 sayılı Resmi Gazete.

Turan, M. (2015), "Hukukumuzda Kişisel Verilerin Korunması", Kalkınma Dergisi, 80, 2-5.

Turan, M. (2016), “Kişisel Verilerin Korunması”, Kalkınma Dergisi, 80, 2-7.

Van Den Broek, T., Ooms, M., Friedewald, M.. Van Lieshout, M. ve Rung, S. (2017), Privacy and Security: Citizens' Desires for an Equal Footing, Surveillance, Privacy and Security: Citizens' Perspectives, Editors: Michael Friedewald, J. Peter Burgess, Johann Ćas, Rocco Bellanova \& Walter Peissl. New Security Studies, Taylor \& Francis Press, 15-35. 
Yüksel, S. (2012), Özel Yaşamın Bir Parçası Olarak Telekomünikasyon Yoluyla Yapılan İletişimin Gizliliğine Önleyici Denetimle Müdahale, İstanbul: Beta Yayınları.

Yüksel, S., Dinçer, H. ve Hacığlu, Ü. (2015), "CAMELS-based Determinants for the Credit Rating of Turkish Deposit Banks", International Journal of Finance \& Banking Studies, 4(4), 1-17. 